\title{
Leptin and the Cardiovascular System
}

\author{
Kamal Rahmouni and William G. Haynes \\ Specialized Center of Research in Hypertension Genetics, Department of Internal Medicine, and \\ General Clinical Research Center, University of Iowa, Iowa City, Iowa 52242
}

\begin{abstract}
Obesity is associated with increased cardiovascular morbidity and mortality, in part through development of hypertension. Recent observations suggest that the cardiovascular actions of leptin may help explain the link between excess fat mass and cardiovascular diseases. Leptin is an adipocyte-derived hormone that acts in the central nervous system to promote weight loss by decreasing food intake and increasing metabolic rate. Leptin causes a significant increase in overall sympathetic nervous activity, which appears to be due to direct hypothalamic effects and is mediated by neuropeptide systems such as the melanocortin system and corticotropin-releasing hormone. Renal sympathoactivation to leptin is preserved in the presence of obesity, despite resistance to the metabolic effects of leptin. Such selective leptin resistance, in the context of circulating hyperleptinemia, could predispose to obesity-related hypertension. Some in vitro studies have suggested that leptin may have peripheral actions such as endothelium-mediated vasodilation that might oppose sympathetically induced vasoconstriction. However, we and others have shown that leptin does not have direct vasodilator effects in vivo. The fact that chronic leptin administration or overexpression of leptin produces hypertension supports the concept that the hemodynamic actions of leptin are due predominantly to sympathetic activation. Exploration of the sites and mechanisms of leptin resistance should provide novel therapeutic strategies for obesity, insulin resistance, and hypertension.
\end{abstract}

\section{Introduction}

Obesity has become one of the most-serious health problems in industrialized societies. Weight gain is associated with a high risk of developing cardiovascular and metabolic diseases such as coronary heart disease, hypertension, diabetes, and dyslipidemia. Epidemiological studies have documented a close relationship between body mass index (BMI) and cardiovascular events (Hubert et al., 1983; Kushner, 1993; Kopelman, 2000). The association between body weight and blood pressure has been found even in normotensive subjects with normal BMI (Stamler et al., 1978; Mikhail and Tuck, 2000). Subsequently, clinical studies have demonstrated that weight loss induced by low-calorie diet or gastric bypass reduces arterial pressure and corrects diabetes and other comorbidities associated with obesity (Carson et al., 1994; Richards et al., 1996). Several experimental models of obesity-induced hypertension have been devel- 
oped. Different species — including the dog, rabbit, rat, and mouse - develop obesity associated with an increase in blood pressure when fed a high-fat diet (Kaufman et al., 1991; Mills et al., 1993; Montani et al., 2002). Some genetic models of obesity (e.g., the Zucker fatty rat, agouti obese mouse) are also used as models of obesity hypertension (Kurtz et al., 1989; Mark et al., 1999).

Until recently adipose tissue was considered exclusively as a body energy store without other function. However, the realization that adipocytes can produce many hormones - including leptin, adiponectin, resistin, atrial natriuretic peptide, and angiotensinogen - have led to a view that this tissue is an endocrine secretory organ (Bradley et al., 2001). Hormones produced by the adipose tissue may act locally to affect adipocyte growth and differentiation or may be released into the circulation to act elsewhere. Among the different hormones released by adipose tissue, leptin has probably drawn the most attention in recent years.

\section{Leptin}

Classical lesion studies established the importance of the hypothalamus in control of energy homeostasis (for a review, see Elmquist et al., 1999). It was then postulated that to control body fat stores, the brain must receive afferent input in proportion to the current level of body fat. Coleman (1973) was the first to demonstrate the existence of a circulating factor that plays a major role in the regulation of body weight. Using parabiosis methodology, he found that obesity in the ob/ob mouse was due to lack of this factor, whereas obesity in the $\mathrm{db} / \mathrm{db}$ mouse was caused by reduced sensitivity to the factor. The much-later cloning of the ob gene revealed the identity of the adiposity factor, which was termed "leptin" (Zhang et al., 1994). This hormone is a 167-amino acid protein expressed mainly by adipocytes and released in the blood in proportion to the size of adipose tissue, which is consistent with leptin's role as a signal of the energy stores (Figure 1). Leptin gene expression and secretion are increased by overfeeding, high-fat diet, insulin, glucocorticoids, endotoxin, and cytokines and decreased by fasting, testosterone, thyroid hormone, and exposure to cold (Coleman and Hermann, 1999; Fried et al., 2000). Leptin gene expression also is modulated by the sympathetic nervous system. For example, we found that blockade of norepinephrine synthesis with alpha-methyl-para-tyrosine or pharmacologic sympathectomy with 6-hydroxydopamine increases leptin mRNA as well as plasma leptin (Sivitz et al., 1999). These observations suggest that the sympathetic nervous system tonically inhibits leptin gene expression through a negative-feedback loop to adipose tissue.

In lean subjects, leptin circulates at low levels (i.e., $5-15 \mathrm{ng} / \mathrm{ml}$ ) as a free form and attached to binding proteins (Sinha et al., 1996). Plasma leptin is transported to the central nervous system (CNS) by a saturable, unidirectional 


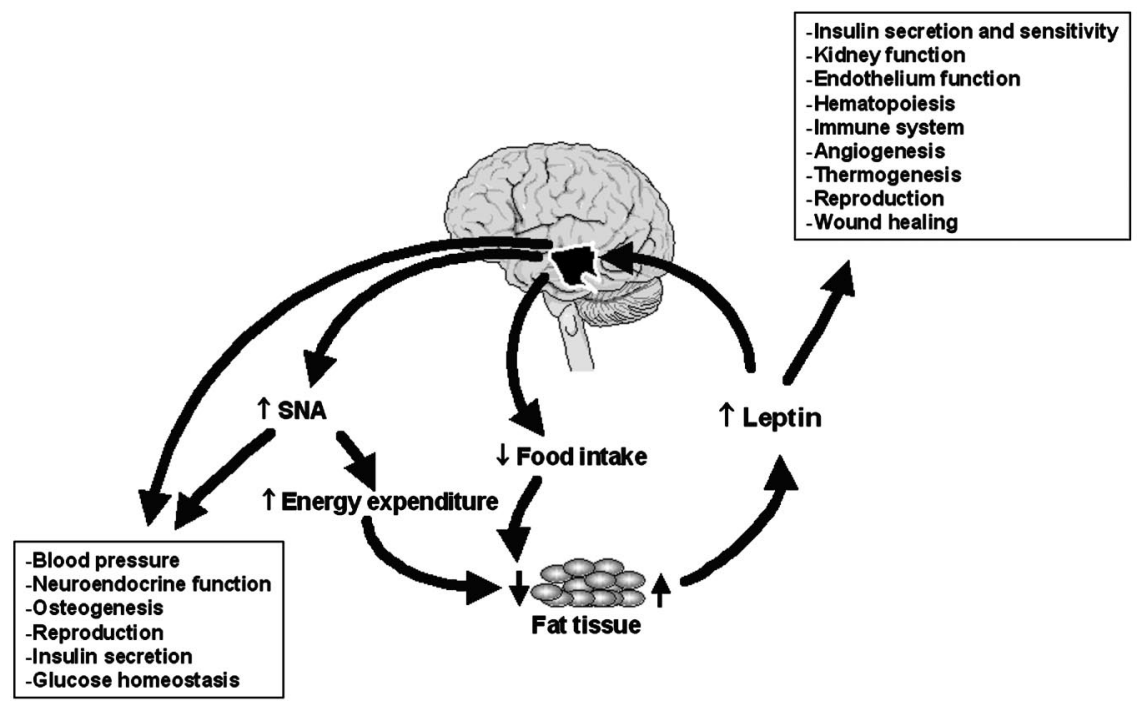

FIG. 1. Role of leptin in the regulation of body weight and other functions. Leptin is secreted by adipocytes and circulates in the blood in a concentration proportional to fat mass content. Action of leptin on its receptor present in the hypothalamus inhibits food intake and increases energy expenditure through stimulation of sympathetic nerve activity (SNA). Leptin modulates different other functions by direct peripheral action in various tissues or through the modulation of SNA.

system (Banks et al., 1996), involving binding of leptin to the short form of the leptin receptor located at the endothelium of the vasculature and the epithelium of choroid plexus (Bjorbaek et al., 1998a). Some evidence suggests that leptin also may be produced in the brain (Wiesner et al., 1999); however, the physiological role of leptin produced locally in the brain and its autocrine and/or paracrine effects remain unknown. Leptin action in the CNS promotes weight loss by decreasing food intake and increasing energy expenditure (Figure 1). The severe obesity and hyperphagia caused by the absence of leptin in rodents and humans demonstrate the importance of this hormone for the control of body weight and food intake (Friedman and Halaas, 1998). Although the main role of leptin is as an adipostat, more-recent studies have shown that leptin has a broad range of effects in different tissues (Wauters et al., 2000; Margetic et al., 2002). Leptin affects these different functions either by direct action in peripheral tissues or through its action in the CNS (Figure 1).

\section{Leptin Receptor and Mechanisms of Signaling}

The leptin receptor is a protein with a single transmembrane domain belonging to the cytokine superfamily. Six different alternatively spliced iso- 
forms of this receptor have been identified (designated Ob-Ra to Ob-Rf) (Tartaglia, 1997). Five isoforms (Ob-Ra to Ob-Rd and Ob-Rf) share an identical extracellular domain but differ in the length of their intracellular domain. Ob-Re, which lacks both the transmembrane and intracellular domains, is a soluble form of the receptor. The $\mathrm{Ob}-\mathrm{Rb}$ form that encodes the full receptor, including the long intracellular domain, appears to mediate most of the biological effects of leptin (Chen et al., 1996; Tartaglia, 1997). As predicted by parabiosis studies, the $\mathrm{db} / \mathrm{db}$ mouse lacks the $\mathrm{Ob}-\mathrm{Rb}$ form of the receptor, resulting from premature stop codon at the 3'-end of the Ob-Rb transcript (Chen et al., 1996; Chua et al., 1996). In contrast, the obese Zucker rat lacks all forms of the leptin receptor, caused by an amino acid substitution (glutamine $\rightarrow$ proline) in the extracellular domain common to all known isoforms of the leptin receptor (Iida et al., 1996; Phillips et al., 1996).

The janus kinase/signal transducer and activator of transcription (JAK/ STAT) pathway was the first signaling mechanism associated with the leptin receptor (Vaisse et al., 1996). Activation of this signaling pathway in the hypothalamus is initiated upon the conformational changes in the leptin receptor triggered by leptin binding. Intracellular JAK proteins (JAK2 and possibly JAK1) that are associated with the binding motifs located in the proximal region of the leptin receptor then are activated by transphosphorylation. Activated JAK proteins, in turn, phosphorylate tyrosine residues of the receptor, providing docking sites for STAT proteins, which become tyrosine-phosphorylated by JAK. Phosphorylated STAT molecules dimerize and translocate to the nucleus to modulate the transcription of target genes (Figure 2). While in vitro studies have shown that leptin receptors signal through different STAT molecules, in vivo studies have demonstrated that, in the hypothalamus, this occurs specifically through activation of STAT3 (Bates et al., 2003). Leptin's effects on the newly identified suppressors of the cytokine signaling family (SOCS) represent a negative-feedback mechanism for this pathway (Bjorbaek et al., 1998b; Emilsson et al., 1999). SOCS proteins negatively regulate the JAK/STAT pathway, either by directly blocking JAKs or through inhibition of further STAT phosphorylation.

More recently, several other intracellular signaling mechanisms have been associated with the leptin receptor. By engaging JAK2, the leptin receptor is able to stimulate insulin receptor substrate (IRS)-2, which, in turn, activates phosphoinositol-3 kinase $\left(\mathrm{PI}_{3}-\mathrm{K}\right)$ through an association to its regulatory subunit (Niswender et al., 2001). This pathway appears to be involved not only in the modulation of neuronal firing rate via the activation of the potassium-adenosine triphosphate (ATP) channels (Niswender and Schwartz, 2003) but also in the modulation of gene transcription through a phosphodiesterase 3-cyclic adenosine monophosphate (cAMP) mechanism (Zhao et al., 2002). The leptin receptor also was found to be able to activate the extracellular factor-regulated kinases 


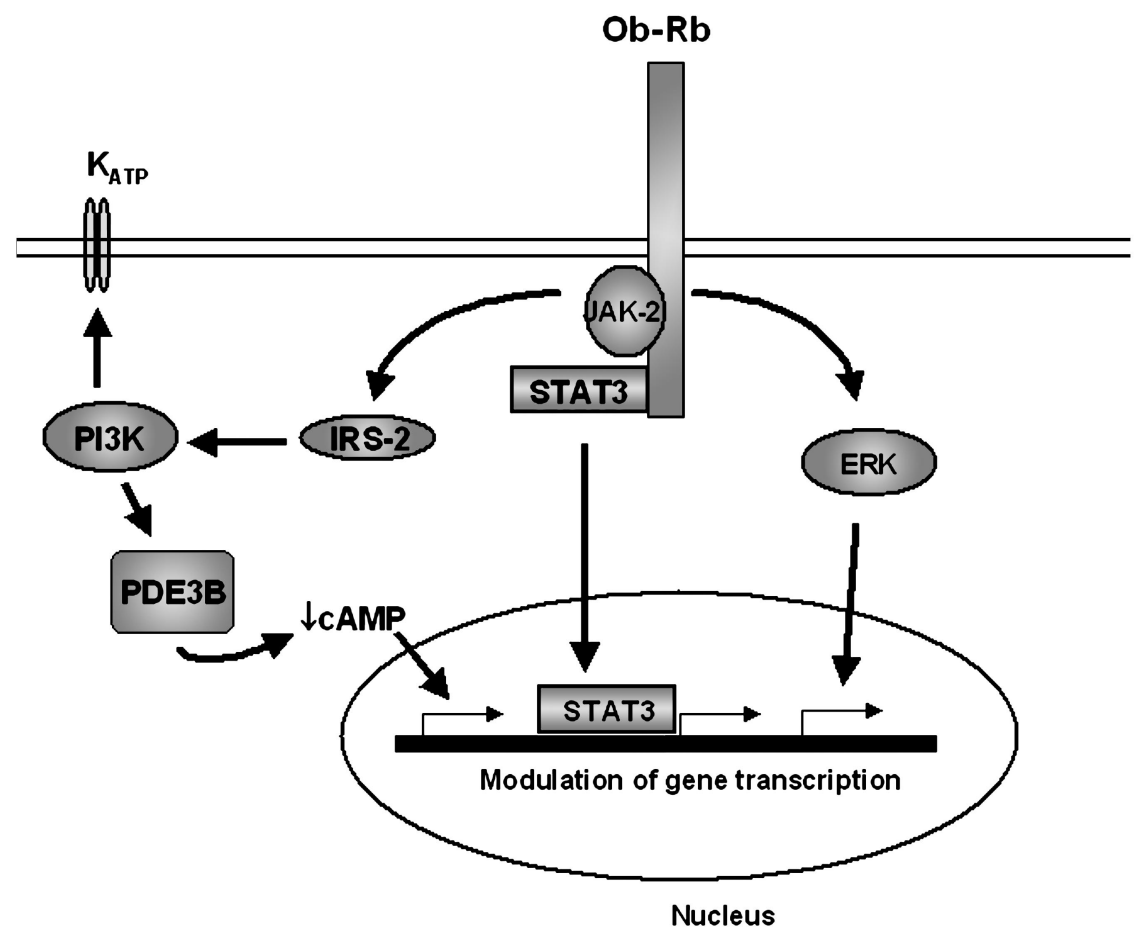

FIG. 2. Molecular mechanisms involved in leptin receptor $(\mathrm{Ob}-\mathrm{Rb})$ signaling in the hypothalamus. Leptin modulates gene transcription via activation of signal transducer and activator of transcription (STAT) proteins, phosphoinositol 3 kinase (PI3-K, via the phosphodiesterase 3B $(\mathrm{PDE} 3 \mathrm{~B})$ ), and a member of the mitogen-activated protein kinase, extracellular factor-regulated kinase (ERK). The PI3-K pathway also appears to be involved in the modulation of neuronal firing rate via the activation of the potassium-adenosine triphosphate channels $\left(\mathrm{K}_{\mathrm{ATP}}\right)$.

(ERKs), a member of the mitogen-activated protein kinase (MAPK) (Bjorbaek et al., 2001; Bates et al., 2003), by different mechanisms, including direct phosphorylation by JAK2. This ERK pathway appears to be involved in leptininduced immediate early-response gene expression, c-fos.

\section{Leptin and the Sympathetic Nervous System}

\section{A. SYMPATHETIC EFFECTS OF LEPTIN}

Consistent with its role in the regulation of energy expenditure, leptin was found to increase norepinephrine turnover in brown adipose tissue (BAT) (Collins et al., 1996), suggesting activation of sympathetic outflow to this tissue. 
Using multifiber recording of regional sympathetic nerve activity (SNA), we evaluated the effects of leptin on the sympathetic outflow to different beds (Haynes et al., 1997). As expected, we found that intravenous administration of leptin in anesthetized Sprague-Dawley rats caused a significant and dosedependent increase in SNA to BAT (Figure 3). Unexpectedly, leptin caused sympathoactivation to other beds not usually considered thermogenic, such as the kidney, hindlimb, and adrenal. Satoh et al. (1999) investigated the effect of leptin on circulating catecholamines and found that leptin administration caused a significant and dose-dependent increase in plasma concentration of norepinephrine and epinephrine.

We have shown that the leptin-induced regional increases in SNA respond nonuniformly to baroreflex activation and hypothermia (Hausberg et al., 2002a,b). Leptin-induced increases in renal SNA can be suppressed by baroreflex activation, suggesting that the increase in renal SNA subserves circulatory functions. In contrast, leptin-induced BAT sympathoactivation was not prevented by baroreflex activation, suggesting the recruitment of sympathetic fibers that serve thermogenic or metabolic, rather than circulatory, functions (Hausberg et al., 2002a). The effect of leptin on regional SNA response to hypothermia differs

\section{BAT SNA}
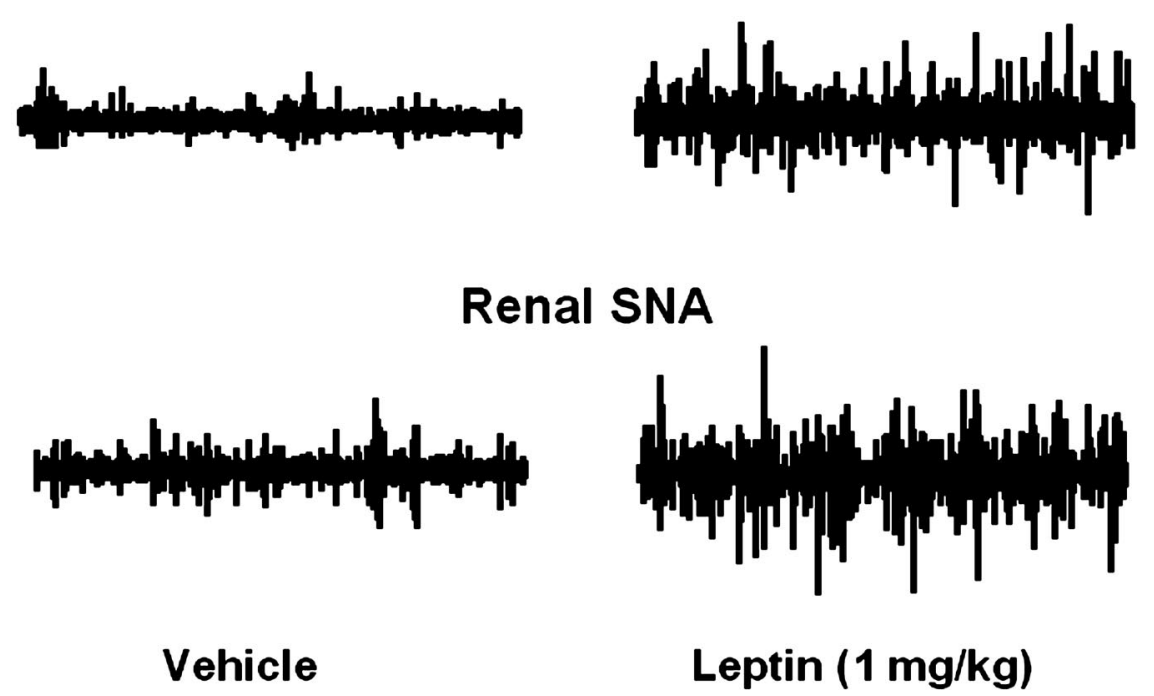

FIG. 3. Effects of intravenous administration of leptin $(1 \mathrm{mg} / \mathrm{kg})$, as compared to vehicle, on SNA to brown adipose tissue (BAT) and kidney in Sprague-Dawley rats. Leptin caused significant increases in both renal and BAT SNA. 
between sympathetic fibers that serve circulatory or thermogenic functions. Leptin, at a low dose that does not alter baseline SNA, acutely enhances sympathetic outflow to BAT in response to hypothermia in lean rats. This effect is specific for thermogenic SNA because leptin does not affect the response of renal SNA to hypothermia (Hausberg et al., 2002b).

Although some reports have shown that leptin could increase SNA through stimulation of peripheral afferent nerves (Niijima et al., 1998; Tanida et al., 2000), our data support the concept that sympathoactivation to leptin is due to the action of this hormone in the CNS. First, leptin-induced sympathoexcitation remains apparent after transection of the sympathetic nerves distal to the recording site and disappears after ganglion blockade with intravenous chlorisondamide (Haynes et al., 1997). These findings indicate that the increase in SNA resulted from efferent sympathetic nerves rather than afferent nerves. Second, direct administration of leptin to the third cerebral ventricle, at subsystemic doses, increases SNA (Haynes, 2000) and dose-dependently increases plasma catecholamines (Satoh et al., 1999). Third, sympathoactivation to intravenous leptin can be abolished completely by selective lesioning of the hypothalamic arcuate nucleus (Haynes, 2000). The arcuate nucleus of the hypothalamus is also considered the major site of leptin action to control body weight and food intake (Schwartz et al., 2000).

In humans, there is no direct evidence for a role of leptin in the regulation of the sympathetic nervous system because results from leptin infusions in humans are lacking. In nonhuman primates, however, leptin has been shown to activate the sympathetic nervous system, as assessed by an increase in circulating norepinephrine levels after a single cerebroventricular administration of leptin (Tang-Christensen et al., 1999). Indirect evidence suggests that leptin may be important for control of SNA in humans. A positive and significant correlation between muscle SNA and plasma leptin concentration has been reported in healthy, nondiabetic men (Snitker et al., 1997). Also, serum leptin levels are a strong positive determinant of resting metabolic rate, which is under sympathetic control, suggesting that action of leptin on SNA is a determinant of energy expenditure in humans. In addition, Jeon et al. (2003) have shown that the correlation between leptin and resting metabolic rate is lost in patients with a disrupted sympathetic nervous system caused by spinal cord injury. These patients had also a lower resting metabolic rate. Together, these findings strongly support the concept that leptin influences energy expenditure through the sympathetic nervous system in humans.

\section{B. SYMPATHETIC EFFECTS OF LEPTIN IN OBESITY}

Several lines of evidence suggest that obesity is associated with activation of the sympathetic nervous system. Plasma and urinary catecholamines are in- 
creased in obese humans as well as in obese animal models (Sowers et al., 1982; Young and Landsberg, 1982; Rocchini et al., 1989). Using direct measurement with microneurography, several groups have shown increased SNA to skeletal muscle in obese subjects, as compared to lean individuals (Vollenweider et al., 1994; Grassi et al., 1995). Norepinephrine spillover techniques have demonstrated that human obesity is associated with increased SNA to a key organ of the cardiovascular homeostasis, the kidney (Vaz et al., 1997). Elevated renal SNA is also reported in animal models of obesity, including rats on high-fat diet (Iwashita et al., 2002). These findings demonstrate that enhanced SNA is a common feature of obesity, which would play a major role in obesity-induced hypertension and cardiovascular disease (Hall et al., 2000). However, the mechanisms responsible for increased SNA in obesity remain unknown.

Obesity is known to be associated with circulating hyperleptinemia, reflecting resistance to leptin because, despite high circulating levels of leptin, such subjects remain obese (Considine et al., 1996). Under these circumstances, in order for leptin to have a role in obesity-related hypertension, one must postulate that any leptin resistance is selective, with preservation of sympathetic responsiveness. Indeed, we have demonstrated that in some animal models, including agouti mice and diet-induced obesity, leptin resistance is selective, with sparing of the effects of leptin on renal SNA. For example, in agouti mice, the anorexic and weight-reducing effects of leptin were less in the obese mice, compared to lean littermates. However, the increase in renal SNA in response to leptin was identical in both lean and obese mice (Correia et al., 2002; Rahmouni et al., 2002). Eikelis et al. (2003) recently have shown the existence of a strong correlation between leptin plasma concentration and renal SNA across a broad range of leptin values in men of widely differing adiposity. This indicates that leptin may be the main cause of sympathoactivation associated with obesity in both animal models and humans (Figure 4).

\section{MECHANISMS OF LEPTIN-INDUCED SYMPATHOACTIVATION}

The receptor-mediated sympathoexcitatory effect of leptin is supported by the absence of SNA response to leptin in obese Zucker rats (Haynes et al., 1997). However, it was not clear which form of the leptin receptor was involved, since Zucker rats lack all forms of the leptin receptor. We recently demonstrated an absence of renal SNA response to leptin in $\mathrm{db} / \mathrm{db}$ mice that indicates that the effects of leptin on sympathetic outflow are mediated by the long-form $\mathrm{Ob}-\mathrm{Rb}$ of the leptin receptor (Rahmouni et al., 2003b).

As mentioned earlier, the leptin receptor has divergent signaling capacities and modulates the activity of different intracellular enzymes. Although STAT signaling was thought to be the main pathway that mediates the leptin action in the hypothalamus, $\mathrm{PI}_{3}-\mathrm{K}$ has been found to play a pivotal role in the effect of 


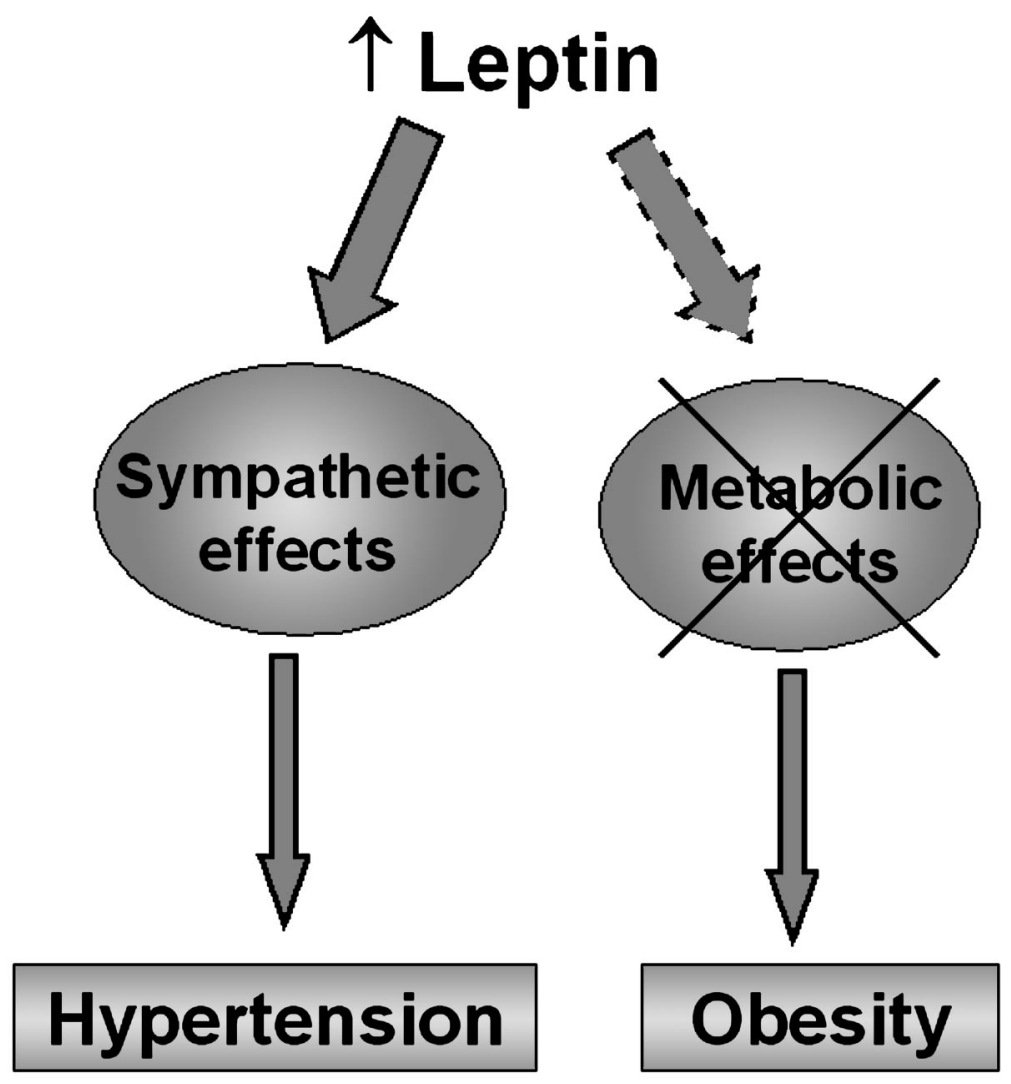

FIG. 4. Concept of selective leptin resistance: there is resistance to the appetite- and weightreducing actions of leptin but preservation of the sympathetic actions. This phenomenon might explain in part how hyperleptinemia could be accompanied by obesity (partial loss of appetite and metabolic actions of leptin) but still contribute to sympathetic overactivity and hypertension because of preservation of the sympathetic actions of leptin to some organs involved in blood pressure regulation (e.g., kidney).

leptin on food intake (Niswender and Schwartz, 2003). Our group has demonstrated that $\mathrm{PI}_{3}-\mathrm{K}$ plays a major role in the transduction of leptin-induced changes in renal sympathetic outflow. We compared renal sympathoactivation to leptin before and after intracerebral administration of $\mathrm{PI}_{3}-\mathrm{K}$ inhibitors. Both LY294002 and wortmannin markedly attenuated the increase in renal SNA induced by leptin, without affecting sympathoactivation to stimulation of the melanocortin system (Rahmouni et al., 2003a). The role of $\mathrm{PI}_{3}-\mathrm{K}$ and other pathways in leptin-induced sympathoactivation to different other beds - including BAT, hindlimb, and adrenal gland - remains unknown. Leptin likely controls sym- 
pathetic nerve activity in a tissue-specific manner, for several reasons. First, activation of arterial baroreceptors and hypothermia modulate differentially leptin-induced sympathoactivation to the kidney and BAT (Hausberg et al., 2002a,b). Second, in diet-induced obese mice, lumbar SNA responses to leptin are attenuated, as compared to lean mice, whereas leptin-induced increases in renal SNA occur with the same time course and magnitude in both diet-induced obese and lean mice (K. Rahmouni, D.A. Morgan, A.L. Mark, W.G. Haynes, unpublished data).

Several hypothalamic neuropeptides, monoamines, and other transmitter substances have been identified as candidate mediators of leptin action in the hypothalamus. These include melanocortins, neuropeptide Y (NPY), corticotropin-releasing hormone $(\mathrm{CRH})$, melanin-concentrating hormone, and cocaine- and amphetamine-regulated transcript (CART) (Schwartz et al., 2000). Therefore, leptin could cause regional sympathoactivation through stimulation of different neuropeptides. In the neural melanocortin system, alpha-melanocyte stimulating hormone $(\alpha-\mathrm{MSH})$ is derived from pro-opiomelanocortin (POMC) and acts mainly on melanocortin-4 receptors (MC-4R). Both renal and lumbar sympathoactivation to leptin seem mediated by the melanocortin system because blockade of melanocortin receptors with SH9119 (Haynes et al., 1999) or agouti protein (Dunbar and Lu, 1999) inhibits the renal and lumbar SNA response to leptin. However, SHU9119 does not block leptin-induced sympathoactivation to BAT (Haynes et al., 1999). Using a MC-4R knockout mouse, we recently confirmed that the renal SNA response to leptin is mediated by MC-4R. Indeed, we have shown a gene dose effect, with MC4-R heterozygotes having 50\% of the normal response to leptin and homozygote knockouts having no renal SNA response to leptin (Rahmouni et al., 2003b). The interrelationship between leptin and the melanocortin system appears to be more complex than first thought because absence of the leptin receptor in $\mathrm{db} / \mathrm{db}$ mice attenuates the renal SNA response to stimulation of the MC-3/4R with MTII (Rahmouni et al., 2003b). This was not expected because the melanocortin system was considered downstream to leptin. Although the mechanisms of this attenuated SNA response to MTII in $\mathrm{db} / \mathrm{db}$ mice remain unknown, one possibility relates to the increased expression of the agouti-related protein in these mice (Korner et al., 2001), which is known to at least partially block the melanocortin receptors in the brain.

The increase in BAT SNA seems to depend on neuropeptides other than the melanocortin system. Given that intracerebral CRH increases SNA to BAT, we investigated the role of this system in leptin-induced sympathoactivation to this tissue. Our results show that a CRH receptor antagonist blocked leptin-induced sympathoactivation to BAT but not to the kidney (Correia et al., 2001a). In summary, leptin appears to causes regional sympathoactivation via different neuropeptide pathways, with melanocortins mediating renal sympathoactivation and CRF mediating BAT SNA to leptin. 


\section{Leptin and Blood Pressure}

\section{A. PRESSOR EFFECTS OF LEPTIN}

Leptin-induced activation of SNA to organs such as the kidney was the first indication of the potential role of this hormone in regulation of blood pressure. The sympathetic nervous system is an important component in the control of renal function (DiBona and Kopp, 1997). Long-term renal sympathetic stimulation by leptin would be expected to raise arterial pressure by causing vasoconstriction and by increasing renal tubular sodium reabsorption. Dunbar et al. (1997) have shown that the sympathoactivation to leptin is followed by a slow but progressive increase in mean arterial pressure. Shek et al. (1998) demonstrated that intravenous infusion of leptin at a dose that increased plasma leptin from 1 to $94 \mathrm{ng} / \mathrm{ml}$ for 12 days increased arterial pressure and heart rate, despite a decrease in food intake that would be expected to decrease arterial pressure. Leptin-induced increases in arterial pressure probably are due to a central neural action of this hormone because intracerebroventricular administration of leptin mimics the effects of systemic administration (Correia et al., 2001b). The substantial dose-dependent increase in heart rate, as well as the greater response to air-jet stress observed in leptin-treated rats, supports central activation of the sympathetic nervous system (Correia et al., 2001b). Finally, blockade of the adrenergic system inhibits the pressor response to leptin (Carlyle et al., 2002).

Further evidence for the pressor effects of leptin derives from studies of transgenic mice overexpressing leptin in the liver (Aizawa-Abe et al., 2000). These mice had 10-fold increases in plasma leptin and decreased body weight. Despite the decreased body weight, the transgenic mice overexpressing leptin had significantly higher arterial pressure than nontransgenic littermates. The transgenic mice also had increased urinary excretion of norepinephrine, a marker of sympathetic nervous system activity. The increase in arterial pressure was normalized after alpha-adrenergic or ganglionic blockade, again demonstrating the importance of the sympathetic nervous system in the pressor effects of leptin.

We evaluated arterial pressure in obese, leptin-deficient ob/ob mice and their wild-type, lean controls (Mark et al., 1999). Despite body weights nearly twice as high as their lean controls, the leptin-deficient ob/ob mice had lower arterial pressure. Aizawa-Abe et al. (2002) subsequently reported that administration of leptin to ob/ob mice (so-called leptin reconstitution) increased systolic blood pressure by as much as $25 \mathrm{mmHg}$, despite decreases in food intake and body weight. These findings demonstrate that leptin contributes physiologically to the regulation of arterial pressure.

In contrast to leptin-deficient ob/ob mice, agouti yellow obese mice have elevated arterial pressure, despite the fact that they have milder obesity than ob/ob mice (Mark et al., 1999). Obesity induced by a high-fat diet is also 
associated with an increase in arterial pressure (Mills et al., 1993; Iwashita et al., 2002). The presence of high circulating levels of leptin associated with the selectivity in leptin resistance (i.e., preserved ability of leptin to increase renal SNA) (Figure 4) could explain the hypertension in these different models of obesity. Other mechanisms may contribute to the development of obesity-related hypertension. For example, in vitro studies have shown that leptin causes oxidative stress in cultured endothelial cells by increasing the generation of reactive oxygen species (ROS) (Bouloumie et al, 1999; Yamagishi et al., 2001). Leptin also has been shown to stimulate the secretion of proinflammatory cytokines (e.g., tumor necrosis factor-alpha, interleukin-6) that are known to promote hypertension (Loffreda et al., 1998).

As has been described for renal SNA, the melanocortin system appears to mediate the effect of leptin on blood pressure. First, pharmacological activation of melanocortin receptors for 14 days caused significant increases in arterial pressure, despite decreases in food intake and body weight (Kuo et al., 2003). Second, inhibition of melanocortin receptors blocks the increase in blood pressure induced by leptin (Dunbar and Lu, 1999).

In order to investigate whether the increase in arterial pressure induced by leptin is due to enhanced salt sensitivity, we studied the effects of a high-salt diet on the pressor responses of intracerebroventricular administration of leptin. The increase in arterial pressure was similar in leptin-treated rats fed a low- or high-salt diet, indicating that leptin-dependent mechanisms in the CNS do not alter arterial pressure sensitivity to salt (Correia et al., 2001b).

In humans, several studies have shown that plasma leptin is related to blood pressure in both normotensive and hypertensive subjects (Hirose et al., 1998; Schorr et al, 1998). A positive correlation has been observed between longitudinal changes in leptin and the arterial pressure (Itoh et al., 2002). Farooqi et al. (1999) have reported that replacement leptin therapy in a child with congenital leptin deficiency for 1 year caused a drastic decrease in body weight $(16 \mathrm{~kg})$. This weight loss would be expected to lower arterial pressure substantially but the arterial pressure did not change. These observations are consistent with a pressor action of leptin offsetting the depressor action of weight loss.

\section{B. DEPRESSOR EFFECTS OF LEPTIN}

Recently, several studies have suggested that leptin may have direct vascular effects that tend to decrease arterial pressure. The vascular endothelium is an important component in the control of arterial pressure homeostasis (Contreras et al., 2000). Endothelial cells release several vasoactive factors, of which nitric oxide (NO) is perhaps the most important with potent vasodilator action. Functionally competent leptin receptors are present on endothelial cells (SierraHonigmann et al., 1998) and leptin administration in rat causes a dose-dependent 
increase in NO metabolite concentrations. In one study in anesthetized rats, infusion of leptin during inhibition of NO synthesis increased arterial pressure (Fruhbeck, 1999). Leptin also decreased arterial pressure after suppression of sympathetic influence using ganglionic blockade (Fruhbeck, 1999) or chemical symapathectomy (Lembo et al., 2000). Furthermore, in vitro studies have shown that leptin evokes an endothelium-dependent relaxation of arterial rings (Kimura et al., 2000; Lembo et al., 2000). Therefore, it has been argued that these vasodilator effects of leptin might oppose its neurogenic pressor action.

In contrast to these reports, Gardiner et al. (1999) found no evidence for a vasodilator action of leptin in conscious rats. These authors showed that leptin does not change blood flow in different beds, including renal, mesenteric, and abdominal arteries. The presence of the NO synthase inhibitor, L-NAME, failed to unmask any pressor effect of leptin (Gardiner et al., 1999). Similarly, we found that leptin does not have substantial direct or indirect vasodilator effects in vivo. Indeed, leptin, at a concentration sufficient to increase sympathetic nerve outflow, did not change arterial pressure or blood flow measured from the mesenteric, lower aortic, and renal arteries (Mitchell et al., 2001). Blockade of the adrenergic system or NO synthase did not reveal any pressor effect of leptin (Mitchell et al., 2001). Furthermore, leptin did not alter the sympathetically mediated vasomotor response in hindlimb or kidney to stimulation of the splanchnic sympathetic nerve trunk (Jalali et al., 2001). Kuo et al. (2001) found that blockade of NO synthesis augmented the heart rate and renal vascular and glomerular responses to leptin but did not substantially augment the pressor response to leptin. Thus, the role of NO in blood pressure responses to leptin remains controversial but consistent negative results of studies in conscious animals argue against a meaningful stimulation of $\mathrm{NO}$ generation.

\section{Renal Effects of Leptin}

Besides the indirect action of leptin on renal function via sympathoactivation, leptin could exert a direct effect on the kidney. In the rat, leptin receptor expression has been found in the inner zone of the medulla and pyramid, associated with the vascular structures, tubules, and ducts (Serradeil-Le Gal et al., 1997). Several investigators have shown that acute administration of leptin in anesthetized or conscious normotensive lean rats produces significant increases in sodium excretion and urine volume without significant effects on renal blood flow, glomerular filtration rate, or potassium excretion (Jackson and Li, 1997; Villarreal et al., 1998; Beltowski et al., 2002). As expected, these saliuretic effects of leptin were blunted in the Zucker rat (Villarreal et al., 2000) but also in high-fat-diet, obese rats (Beltowski et al., 2002). Surprisingly, spontaneously hypertensive rats also were refractory to the diuretic and natriuretic effects of leptin, due perhaps to enhanced renal SNA, because renal denervation restored 
the saliuretic response of these rats to leptin (Villarreal et al., 2000). A subsequent study by Shek et al. (1998) suggested that the natriuretic action of leptin is not operative at physiological levels because a chronic increase in leptin concentrations within the physiological range in rats did not produce natriuresis, despite an increase in arterial pressure. This study (Shek et al., 1998) provided no support for a significant natriuretic action of leptin and instead suggested that leptin actually may produce a modest antinatriuretic effect (probably due to the activation of the renal SNA) that opposes pressure natriuresis.

However, leptin appears to have an important role in obesity-induced renal damage such as glomerular hyperfiltration and increased urinary albumin loss. In glomerular endothelial cells, leptin stimulates cellular proliferation, transforming growth factor-beta ${ }_{1}$ (TGF- $\beta_{1}$ ) synthesis, and type IV collagen production. Conversely, in mesangial cells, leptin upregulates synthesis of the TGF- $\beta$ type II receptor, but not TGF- $\beta_{1}$, and stimulates glucose transport and type I collagen production (Wolf et al., 1999). Chronic leptin treatment induces glumerosclerosis and proteinuria in normal rats (Wolf et al., 1999). Therefore, leptin may be of relevance to the development of glomerular pathology associated with obesity.

\section{Leptin and Other Cardiovascular Risks}

Longitudinal and cross-sectional studies have shown an association between serum leptin concentrations and various cardiovascular risks, including stroke (Soderberg et al., 1999a), chronic heart failure (Leyva et al., 1998; Schulze et al., 2003), acute myocardial infarction (Soderberg et al., 1999b), coronary heart disease (Wallace et al., 2001), and left cardiac hypertrophy (Paolisso et al., 1999). Most of these studies have statistically corrected for differences in body adiposity, though such statistical techniques can be inadequate when there are large differences between groups in confounding variables. Further studies, including animal experimentation, are needed to strengthen and clarify the link between leptin and cardiovascular disease (CVD). The mechanisms by which leptin could contribute to these complications remains unknown. Although the action of leptin in the CNS and the activation of the sympathetic nervous system could play a major role in CVD, the presence of the leptin receptor in the heart suggests that leptin could modulate cardiac function directly (Wold et al., 2002). For example, Nickola et al. (2000) have shown a direct effect of leptin on cardiomyocyte contraction that may contribute to altered myocardial function. Interestingly, the cardiac contractile response to leptin was blunted in the spontaneously hypertensive rat (Wold et al., 2002). An effect of leptin on the adenylate cyclase system, the main effector of beta-adrenergic receptors, was demonstrated in a cardiac cell line (Illiano et al., 2002). 


\section{Conclusion}

The epidemic of obesity has led to an unwelcome epidemic of CVD, including hypertension. The mechanisms of obesity-related CVD are not fully understood but the discovery of leptin and its effects on the sympathetic nervous system may provide a partial explanation. Leptin has diverse cardiovascular actions, although sympathoactivation is probably the most important. The concept of selective leptin resistance may explain how leptin could contribute to obesity-related hypertension, despite loss of its metabolic effects. Increasing knowledge of the mechanisms and sites of leptin resistance should provide new insights into the pathophysiology of obesity and its treatment.

\section{ACKNOWLEDGMENTS}

The authors' work is supported by grants HL44546 and HL14388 from the National Heart, Lung, and Blood Institute and by RR00059 from the National Center for Research Resources General Clinical Research Centers Program. Dr. Rahmouni was supported by a postdoctoral fellowship award from the Heartland Affiliate of the American Heart Association (No. 0120606Z). We thank Sarverne Meyer for superb secretarial assistance.

\section{REFERENCES}

Aizawa-Abe M, Ogawa Y, Masuzaki H, Ebihara K, Satoh N, Iwai H, Matsuoka N, Hayashi T, Hosoda K, Inoue G, Yoshimasa Y, Nakao K 2000 Pathophysiological role of leptin in obesity-related hypertension. J Clin Invest 105:1243-1252

Banks WA, Kastin AJ, Huang W, Jaspan JB, Maness LM 1996 Leptin enters the brain by a saturable system independent of insulin. Peptides 17:305-311

Bates SH, Stearns WH, Dundon TA, Schubert M, Tso AW, Wang Y, Banks AS, Lavery HJ, Haq AK, et al. 2003 STAT3 signaling is required for leptin regulation of energy balance but not reproduction. Nature 421:856-859

Beltowski J, Wjcicka G, Gorny D, Marciniak A 2002 Human leptin administered intraperitoneally stimulates natriuresis and decreases renal medullary $\mathrm{Na}+, \mathrm{K}+$-ATPase activity in the rat impaired effect in dietary-induced obesity. Med Sci Monit 8:BR221-BR229

Bjorbaek C, Elmquist JK, Michl P, Ahima RS, van Bueren A, McCall AL, Flier JS 1998a Expression of leptin receptor isoforms in rat brain microvessels. Endocrinology 139:34853491

Bjorbaek C, Elmquist JK, Frantz JD, Shoelson SE, Flier JS 1998b Identification of SOCS-3 as a potential mediator of central leptin resistance. Mol Cell 1:619-625

Bjorbaek C, Buchholz RM, Davis SM, Bates SH, Pierroz DD, Gu H, Neel BG, Myers MG Jr, Flier JS 2001 Divergent roles of SHP-2 in ERK activation by leptin receptors. J Biol Chem 276:4747-4755

Bouloumie A, Marumo T, Lafontan M, Busse R 1999 Leptin induces oxidative stress in human endothelial cells. FASEB J 13:1231-1238

Bradley RL, Cleveland KA, Cheatham B 2001 The adipocyte as a secretory organ: mechanisms of vesicle transport and secretory pathways. Recent Prog Horm Res 56:329-358

Carlyle M, Jones OB, Kuo JJ, Hall JE 2002 Chronic cardiovascular and renal actions of leptin: role of adrenergic activity. Hypertension 39:496-501 
Carson JL, Ruddy ME, Duff AE, Holmes NJ, Cody RP, Brolin RE 1994 The effect of gastric bypass surgery on hypertension in morbidly obese patients. Arch Intern Med 154:193-200

Chen H, Charlat O, Tartaglia LA, Woolf EA, Weng X, Ellis SJ, Lakey ND, Culpepper J, Moore KJ, Breitbart RE, Duyk GM, Tepper RI, Morgenstern JP 1996 Evidence that the diabetes gene encodes the leptin receptor: identification of a mutation in the leptin receptor gene in $\mathrm{db} / \mathrm{db}$ mice. Cell 84:491-495

Chua SC Jr, Chung WK, Wu-Peng XS, Zhang Y, Liu SM, Tartaglia L, Leibel RL 1996 Phenotypes of mouse diabetes and rat fatty due to mutations in the OB (leptin) receptor. Science 271:994-996

Coleman DL 1973 Effects of parabiosis of obese with diabetes and normal mice. Diabetologia 9:294-298

Coleman RA, Herrmann TS 1999 Nutritional regulation of leptin in humans. Diabetologia 42:639-646

Collins S, Kuhn CM, Petro AE, Swick AG, Chrunyk BA, Surwit RS 1996 Role of leptin in fat regulation. Nature 380:677

Considine RV, Sinha MK, Heiman ML, Kriauciunas A, Stephens TW, Nyce MR, Ohannesian JP, Marco CC, McKee LJ, Bauer TL, et al. 1996 Serum immunoreactive-leptin concentrations in normal-weight and obese humans. N Engl J Med 334:292-295

Contreras F, Rivera M, Vasquez J, De la Parte MA, Velasco M 2000 Endothelial dysfunction in arterial hypertension. J Hum Hypertens 14:S20-S25

Correia MLG, Morgan DA, Mitchell JL, Sivitz WI, Mark AL, Haynes WG 2001a Role of corticotrophin-releasing factor in effects of leptin on sympathetic nerve activity and arterial pressure. Hypertension 38:384-388

Correia ML, Morgan DA, Sivitz WI, Mark AL, Haynes WG 2001b Leptin acts in the central nervous system to produce dose-dependent changes in arterial pressure. Hypertension 37: 936-942

Correia ML, Haynes WG, Rahmouni K, Morgan DA, Mark AL 2002 The concept of selective leptin resistance: evidence from agouti yellow obese mice. Diabetes 51:439-442

DiBona GF, Kopp UC 1997 Neural control of renal function. Physiol Rev 77:75-197

Dunbar JC, Lu H 1999 Leptin-induced increase in sympathetic nervous and cardiovascular tone is mediated by proopiomelanocortin (POMC) products. Brain Res Bull 50:215-221

Dunbar JC, Hu Y, Lu H 1997 Intracerebroventricular leptin increases lumbar and renal sympathetic nerve activity and blood pressure in normal rats. Diabetes 46:2040-2043

Eikelis N, Schlaich M, Aggarwal A, Kaye D, Esler M 2003 Interactions between leptin and the human sympathetic nervous system. Hypertension 41:1072-1079

Elmquist JK, Elias CF, Saper CB 1999 From lesions to leptin: hypothalamic control of food intake and body weight. Neuron 22:221-232

Emilsson V, Arch JR, de Groot RP, Lister CA, Cawthorne MA 1999 Leptin treatment increases suppressors of cytokine signaling in central and peripheral tissues. FEBS Lett 455:170-174

Farooqi IS, Jebb SA, Langmack G, Lawrence E, Cheetham CH, Prentice AM, Hughes IA, McCamish MA, O'Rahilly S 1999 Effects of recombinant leptin therapy in a child with congenital leptin deficiency. N Engl J Med 341:879-884

Fried SK, Ricci MR, Russell CD, Laferrere B 2000 Regulation of leptin production in humans. J Nutrit 130:3127S-3131S

Friedman JM, Halaas JL 1998 Leptin and the regulation of body weight in mammals. Nature 395:763-770

Fruhbeck G 1999 Pivotal role of nitric oxide in the control of blood pressure after leptin administration. Diabetes 48:903-908

Gardiner SM, Kemp PA, March JE, Bennett T 1999 Regional haemodynamic effects of recombinant murine or human leptin in conscious rats. Br J Pharmacol 130:805-810 
Grassi G, Seravalle G, Cattaneo BM, Bolla GB, Lanfranchi A, Colombo M, Giannattasio C, Brunani A, Cavagnini F, Mancia G 1995 Sympathetic activation in obese normotensive subjects. Hypertension 25:560-563

Hall JE, Hildebrandt DA, Kuo J, Fitzgerald S 2000 Role of sympathetic nervous system and neuropeptides in obesity hypertension. Braz J Med Biol Res 33:605-618

Hausberg M, Morgan DA, Chapleau MA, Sivitz WI, Mark AL, Haynes WG 2002a Differential modulation of leptin-induced sympathoexcitation by baroreflex activation. J Hypertens 20:1633-1641

Hausberg M, Morgan DA, Mitchell JL, Sivitz WI, Mark AL, Haynes WG 2002b Leptin potentiates thermogenic sympathetic responses to hypothermia: a receptor-mediated effect. Diabetes 51:2434-2440

Haynes WG 2000 Interaction between leptin and sympathetic nervous system in hypertension. Curr Hypertens Rep 2:311-318

Haynes WG, Morgan DA, Walsh SA, Sivitz WI, Mark AL 1997 Receptor-mediated regional sympathetic nerve activation by leptin. J Clin Invest 100:270-278

Haynes WG, Morgan DA, Djalali A, Sivitz WI, Mark AL 1999 Interactions between the melanocortin system and leptin in control of sympathetic nerve traffic. Hypertension 33:542547

Hirose H, Saito I, Tsujioka M, Mori M, Kawabe H, Saruta T 1998 The obese gene product, leptin: possible role in obesity-related hypertension in adolescents. J Hypertens 16:2007-2012

Hubert HB, Feinleib M, McNamara PM, Castelli WP 1983 Obesity as an independent risk factor for cardiovascular disease: a 26-year follow-up of participants in the Framingham Heart Study. Circulation 67:968-977

Iida M, Murakami T, Ishida K, Mizuno A, Kuwajima M, Shima K 1996 Substitution at codon 269 (glutamine $\rightarrow$ proline) of the leptin receptor (OB-R) cDNA is the only mutation found in the Zucker fatty (fa/fa) rat. Biochem Biophys Res Commun 224:597-604

Illiano G, Naviglio S, Pagano M, Spina A, Chiosi E, Barbieri M, Paolisso G 2002 Leptin affects adenylate cyclase activity in $\mathrm{H} 9 \mathrm{c} 2$ cardiac cell line: effects of short- and long-term exposure. Am J Hypertens 15:638-643

Itoh K, Imai K, Masuda T, Abe S, Tanaka M, Koga R, Itoh H, Matsuyama T, Iwashita S, Tanida M, Terui N, Ootsuka Y, Shu M, Kang D, Suzuki M 2002 Relationship between changes in serum leptin levels and blood pressure after weight loss. Hyperten Res 25:881-886

Iwashita S, Tanida M, Terui N, Ootsuka Y, Shu M, Kang D, Suzuki M 2002 Direct measurement of renal sympathetic nervous activity in high-fat diet-related hypertensive rats. Life Sci 71(5):537-546

Jackson EK, Li P 1997 Human leptin has natriuretic activity in the rat. Am J Physiol 272:F333F338

Jalali A, Morgan DA, Sivitz WI, Correia ML, Mark AL, Haynes WG 2001 Does leptin cause functional peripheral sympatholysis? Am J Hypertens 14:615-618

Jeon JY, Steadward RD, Wheeler GD, Bell G, McCargar L, Harber V 2003 Intact sympathetic nervous system is required for leptin effects on resting metabolic rate in people with spinal cord injury. J Clin Endocrinol Metab 88:402-407

Kaufman LN, Peterson MM, Smith SM 1991 Hypertension and sympathetic hyperactivity induced in rats by high-fat or glucose diets. Am J Physiol 260:E95-E100

Kimura K, Tsuda K, Baba A, Kawabe T, Boh-oka S, Ibata M, Moriwaki C, Hano T, Nishio I 2000 Involvement of nitric oxide in endothelium-dependent arterial relaxation by leptin. Biochem Biophys Res Commun 273:745-749

Kopelman PG 2000 Obesity as a medical problem. Nature 404:635-643

Korner J, Savontaus E, Chua SC Jr, Leibel RL, Wardlaw SLJ 2001 Leptin regulation of Agrp and NPY mRNA in the rat hypothalamus. Neuroendocrinology 13:959-966 
Kuo JJ, Jones OB, Hall JE 2001 Inhibition of NO synthesis enhances chronic cardiovascular and renal actions of leptin. Hypertension 37:670-676

Kuo JJ, Silva AA, Hall JE 2003 Hypothalamic melanocortin receptors and chronic regulation of arterial pressure and renal function. Hypertension 41:768-774

Kurtz TW, Morris RC, Pershadsingh HA 1989 The Zucker fatty rat as a genetic model of obesity and hypertension. Hypertension 13:896-901

Kushner RF 1993 Body weight and mortality. Nutrit Rev 51:127-136

Lembo G, Vecchione C, Fratta L, Marino G, Trimarco V, d'Amati G, Trimarco B 2000 Leptin induces direct vasodilation through distinct endothelial mechanisms. Diabetes 49(2):293-297

Leyva F, Anker SD, Egerer K, Stevenson JC, Kox WJ, Coats AJ 1998 Hyperleptinaemia in chronic heart failure. Relationships with insulin. Eur Heart J 19:1547-1551

Loffreda S, Yang SQ, Lin HZ, Karp CL, Brengman ML, Wang DJ, Klein AS, Margetic S, Gazzola C, Pegg GG, Hill RA 1998 Leptin regulates proinflammatory immune responses. FASEB J 12:57-65

Margetic S, Gazzola C, Pegg GG, Hill RA 2002 Leptin: a review of its peripheral actions and interactions. Intl J Obes Relat Metab Disord 26(11)1407-1433

Mark AL, Shaffer RA, Correia ML, Morgan DA, Sigmund CD, Haynes WG 1999 Contrasting blood pressure effects of obesity in leptin-deficient ob/ob mice and agouti yellow obese mice. J Hypertens 17:1949-1953

Mikhail N, Tuck ML 2000 Epidemiological and clinical aspects of obesity related hypertension. J Clin Hypertens (Greenwich) 2:41-45

Mills E, Kuhn CM, Feinglos MN, Surwit R 1993 Hypertension in CB57BL/6J mouse model of non-insulin-dependent diabetes mellitus. Am J Physiol 264:R73-R78

Mitchell JL, Morgan DA, Correia ML, Mark AL, Sivitz WI, Haynes WG 2001 Does leptin stimulate nitric oxide to oppose the effects of sympathetic activation? Hypertension 38:10811086

Montani JP, Antic V, Yang Z, Dulloo A 2002 Pathways from obesity to hypertension: from the perspective of a vicious triangle. Intl J Obes Relat Metab Disord 26:S28-S38

Nickola MW, Wold LE, Colligan PB, Wang GJ, Samson WK, Ren J 2000 Leptin attenuates cardiac contraction in rat ventricular myocytes. Role of NO. Hypertension 36:501-505

Niijima A 1998 Afferent signals from leptin sensors in the white adipose tissue of the epididymis, and their reflex effect in the rat. J Auton Nerv Syst 27:73:19-25

Niswender KD, Schwartz MW 2003 Insulin and leptin revisited: adiposity signals with overlapping physiological and intracellular signaling capabilities. Front Neuroendocrinol 24:1-10

Niswender KD, Morton GJ, Stearns WH, Rhodes CJ, Myers MG Jr, Schwartz MW 2001 Intracellular signaling. Key enzyme in leptin-induced anorexia. Nature 413:794-795

Paolisso G, Tagliamonte MR, Galderisi M, Zito GA, Petrocelli A, Carella C, de Divitiis O, Varricchio M 1999 Plasma leptin level is associated with myocardial wall thickness in hypertensive insulin-resistant men. Hypertension 34:1047-1052

Phillips MS, Liu Q, Hammond HA, Dugan V, Hey PJ, Caskey CJ, Hess JF 1996 Leptin receptor missense mutation in the fatty Zucker rat. Nature Genet 13:18-19

Rahmouni K, Haynes WG, Morgan DA, Mark AL 2002 Selective resistance to central neural administration of leptin in agouti obese mice. Hypertension 39:486-490

Rahmouni K, Haynes WG, Morgan DA, Mark AL 2003a Role of melanocortin-4 receptors in mediating renal sympathoactivation to leptin and insulin. J Neurosci 23(14):5998-6004

Rahmouni K, Haynes WG, Morgan DA, Mark AL 2003b Intracellular mechanisms involved in leptin regulation of sympathetic outflow. Hypertension 41:763-767

Richards RJ, Thakur V, Reisin E 1996 Obesity-related hypertension: its physiological basis and pharmacological approaches to its treatment. J Hum Hypertens 10:S59-S64 
Rocchini AP, Moorhead CP, Deremer S, Bondi D 1989 Pathogenesis of weight-related pressure changes in blood pressure in dogs. Hypertension 13:922-928

Satoh N, Ogawa Y, Katsuura G, Numata Y, Tsuji T, Hayase M, Ebihara K, Masuzaki H, Hosoda K, Yoshimasa Y, Nakao K 1999 Sympathetic activation of leptin via the ventromedial hypothalamus: leptin-induced increase in catecholamine secretion. Diabetes 48:17871793

Schorr U, Blaschke K, Turan S, Distler A, Sharma AM 1998 Relationship between angiotensinogen, leptin and blood pressure levels in young normotensive men. J Hypertens 16:1475-1480

Schulze PC, Kratzsch J, Linke A, Schoene N, Adams V, Gielen S, Erbs S, Moebius-Winkler S, Schuler G 2003 Elevated serum levels of leptin and soluble leptin receptor in patients with advanced chronic heart failure. Eur J Heart Fail 5:33-40

Schwartz MW, Woods SC, Porte D Jr, Seeley RJ, Baskin DG 2000 Central nervous system control of food intake. Nature 404:661-671

Serradeil-Le Gal C, Raufaste D, Brossard G, Pouzet B, Marty E, Maffrand JP, Le Fur G 1997 Characterization and localization of leptin receptors in the rat kidney. FEBS Lett 404:185-191

Shek EW, Brands MW, Hall JE 1998 Chronic leptin infusion increases arterial pressure. Hypertension 32:376-377

Sierra-Honigmann MR, Nath AK, Murakami C, Garcia-Cardena G, Papapetropoulos A, Sessa WC, Madge LA, Schechner JS, Schwabb MB, Polverini PJ, Flores-Riveros JR 1998 Biological action of leptin as an angiogenic factor. Science 28:683-1686

Sinha MK, Opentanova I, Ohannesian JP, Kolaczynski JW, Heiman ML, Hale J, Becker GW, Bowsher RR, Stephens TW, Caro JF 1996 Evidence of free and bound leptin in human circulation. Studies in lean and obese subjects and during short-term fasting. J Clin Invest 98:1277-1282

Sivitz WI, Fink BD, Morgan DA, Fox JM, Donohoue PA, Haynes WG 1999 Sympathetic inhibition, leptin, and uncoupling protein subtype expression in normal fasting rats. Am J Physiol 277:E668-E677

Snitker S, Pratley RE, Nicolson M, Tataranni PA, Ravussin E 1997 Relationship between muscle sympathetic nerve activity and plasma leptin concentration. Obes Res 5:338-340

Soderberg S, Ahren B, Stegmayr B, Johnson O, Wiklund PG, Weinehall L, Hallmans G, Olsson T 1999a Leptin is a risk marker for first-ever hemorrhagic stroke in a population-based cohort. Stroke 30:328-337

Soderberg S, Ahren B, Jansson JH, Johnson O, Hallmans G, Asplund K, Olsson T 1999b Leptin is associated with increased risk of myocardial infarction. J Intern Med 246:409-418

Sowers JR, Whitfield LA, Catania RA, Stern N, Tuck ML, Dornfeld L, Maxwell M 1982 Role of the sympathetic nervous system in blood pressure maintenance in obesity. J Clin Endocrinol Metab 54:1181-1186

Stamler R, Stamler J, Riedlinger WF, Algera G, Roberts RH 1978 Weight and blood pressure. Findings in hypertension screening of 1 million Americans. JAMA 240:1607-1610

Tang-Christensen M, Havel PJ, Jacobs RR, Larsen PJ, Cameron JL 1999 Central administration of leptin inhibits food intake and activates the sympathetic nervous system in rhesus macaques. J Clin Endocrinol Metab 84:711-717

Tanida M, Iwashita S, Ootsuka Y, Terui N, Suzuki M 2000 Leptin injection into white adipose tissue elevates renal sympathetic nerve activity dose-dependently through the afferent nerves pathway in rats. Neurosci Lett 293:107-110

Tartaglia LA 1997 The leptin receptor. J Biol Chem 272:6093-6096

Vaisse C, Halaas JL, Horvath CM, Darnell JE Jr, Stoffel M, Friedman JM 1996 Leptin activation of Stat3 in the hypothalamus of wild-type and ob/ob mice but not $\mathrm{db} / \mathrm{db}$ mice. Nature Genet 14:95-97 
Vaz M, Jennings G, Turner A, Cox H, Lambert G, Esler M 1997 Regional sympathetic nervous activity and oxygen consumption in obese normotensive human subjects. Circulation 96: 3423-3429

Villarreal D, Reams G, Freeman RH, Taraben A 1998 Renal effects of leptin in normotensive, hypertensive, and obese rats. Am J Physiol 275:R2056-R2060

Villarreal D, Reams G, Freeman RH 2000 Effects of renal denervation on the sodium excretory actions of leptin in hypertensive rats. Kidney Intl 58:989-994

Vollenweider P, Randin D, Tappy L, Jequier E, Nicod P, Scherrer U 1994 Impaired insulininduced sympathetic neural activation and vasodilation in skeletal muscle in obese humans. J Clin Invest 93:2365-2371

Wallace AM, McMahon AD, Packard CJ, Kelly A, Shepherd J, Gaw A, Sattar N 2001 Plasma leptin and the risk of cardiovascular disease in the west of Scotland coronary prevention study (WOSCOPS). Circulation 104:3052-3056

Wauters M, Considine RV, Van Gaal LF 2000 Human leptin: from an adipocyte hormone to an endocrine mediator. Eur J Endocrinol 143:293-311

Wiesner G, Vaz M, Collier G, Seals D, Kaye D, Jennings G, Lambert G, Wilkinson D, Esler M 1999 Leptin is released from the human brain: influence of adiposity and gender. J Clin Endocrinol Metab 84:2270-2274

Wold LE, Relling DP, Duan J, Norby FL, Ren J 2002 Abrogated leptin-induced cardiac contractile response in ventricular myocytes under spontaneous hypertension: role of Jak/STAT pathway. Hypertension 39:69-74

Wolf G, Hamann A, Han DC, Helmchen U, Thaiss F, Ziyadeh FN, Stahl RA 1999 Leptin stimulates proliferation and TGF- $\beta$ expression in renal glomerular endothelial cells: Potential role in glomerulosclerosis. Kidney Intl 56:860-872

Yamagishi SI, Edelstein D, Du XL, Kaneda Y, Guzman M, Brownlee M 2001 Leptin induces mitochondrial superoxide production and monocyte chemoattractant protein-1 expression in aortic endothelial cells by increasing fatty acid oxidation via protein kinase A. J Biol Chem 276:25096-25100

Young JB, Landsberg L 1982 Diet-induced changes in sympathetic nervous system activity: possible implications for obesity and hypertension. J Chronic Dis 35:879-886

Zhang Y, Proenca R, Maffei M, Barone M, Leopold L, Friedman JM 1994 Positional cloning of the mouse obese gene and its human homologue. Nature 372:425-432

Zhao AZ, Huan JN, Gupta S, Pal R, Sahu A 2002 A phosphatidylinositol 3-kinase phosphodiesterase 3B-cyclic AMP pathway in hypothalamic action of leptin on feeding. Nature Neurosci $5: 727-728$ 